УДК 629.424.3

IMPROVING THE DIESEL FUEL QUALITY FOR TRACTIONAL ROLLING STOCK DIESEL ENGINES

Engineer I. I. Kostyria, engineer P. I. Liubenko, PhD (Tech.) O. V. Artemenko, PhD (Tech.) D. O. Aulin

\title{
ПІДВИЩЕННЯ ЯКОСТІ ДИЗЕЛЬНОГО ПАЛИВА ДЛЯ ДИЗЕЛІВ ТЯГОВОГО РУХОМОГО СКЛАДУ
}

Інженери І. І. Костиря, П. І. Любенко, кандидати техн. наук О. В. Артеменко, Д. О. Аулін

Abstract. At the present stage of development of technology and engine building, the use of engines as transport power plants, improving their reliability, efficiency, and reducing the toxicity of diesel fuel combustion products are a cutting issue. In railway transport, traction rolling stock is generally well worn and requires funds to renew it. Thus, there are two ways to improve the technical and economic indicators of locomotives: modernization and application of technical diagnostics, and application of chemmotological methods. The first way is associated with big capital investments and additional time costs. Along with the urgent need for its development and application, the second way pays off much faster in the presence of efficient and affordable treatment methods and chemical additives to diesel oil products.

Keywords: diesel engine, diesel fuel, fuel treatment, additives, efficiency. 
Анотація. Найбільш важливими показниками транспортних дизелів є надійність, ефективність функиіонування $і$ токсичність газів, щчо відробили. В статті розглянуто питання підвищення ефективності функціонування тепловозних дизелів впровадженням технічних та технологічних засобів енергозбереження. На залізничному транспорті тяговий рухомий склад в основному має високий ступінь зношеності і недостатньо коштів для його поновлення. У ичих умовах існують два шляхи поліпшення техніко-економічних показників локомотивів: модернізація та застосування технічної діагностики; застосування хімотологічних заходів. Перший напрям пов'язаний зі значними капітальними вкладеннями і додатковими витратами часу. Поряд з гострою необхідністю його розвитку $i$ застосування другий напрямок, за наявності ефективних і прийнятних за вартістю способів обробки і хімічних добавок до дизельних нафтопродуктів, окупається значно швидше. Поліпшення будь-яких експлуатаційних властивостей дизельного палива через зміну їхнього хімічного складу вимагає величезних витрат, у той же час зміна тих або інших властивостей дизельного палива можлива внаслідок введення у нього присадок, що дають такий же або більший ефект, ніж зміна технології виробництвва або впровадження фізичних методів обробки із застосуванням спеціального бортового або стаціонарного обладнання. Умовно изі заходи можна поділити на два типи: 1) для доведення якості дизельних палив до вимог стандарту; до них належать протизносні, иетанопідвищувальні $i$ депресорно-диспергувальні; 2) для поліпшення експлуатачійних властивостей палив понад вимоги специфікації $i$ надання паливу особливої якості. В результаті дослідження сформульовано технічні вимоги до комплексного заходу щцодо підвищення якості дизельного палива для дизелів тепловозів, запропонована методика визначення ефективності запропонованих заходів при експлуатаційних випробуваннях в умовах депо.

Ключові слова: дизельний двигун, дизельне паливо, обробка палива, присадки, ефективність.

Introduction. Resource conservation is a top-priority problem in resource-intensive industries, which include transport that consumes $13.4 \%$ of the total flow of primary energy resources.

The large focus is on reducing the level of resource use in transport, in particular, on addressing issues of rational consumption and use of material, energy, labor, information, and financial resources [1].

In modern conditions, an important area is to increase the efficiency of fuel and energy resources. This corresponds to the program of development of railway transport of Ukraine. The constant rise in energy prices dictates the need to find new reserves that would reduce fuel costs together with the toxicity of diesel locomotives. It is also due to the high degree of wear of the locomotive fleet of Ukraine, however, the tense economic situation is an obstacle to fully renew the operating fleet of locomotives.
Literature review.There are two main ways to improve the technical, economic, and environmental performance of diesel rolling stock:

- modernization and application of technical diagnostics;

- application of chemmotological measures (use of effective additives to diesel fuel and motor oil, physical methods of fuel and motor oil treatment) [2].

The first area entails big capital investments and additional expenses. The second area pays off much faster if using effective and affordable chemical additives to petroleum products, or equipment for its processing.

Chemmotological measures can be conditionally divided into two types:

- to bring the quality of diesel fuels to the standard requirements; 
- to improve the performance of fuels beyond the specification requirements and obtain fuel of special quality.

The quality of diesel fuel changes significantly during transportation, storage, and other technological operations performed before filling the diesel rolling stock.

The main reasons for changes in the quality of petroleum products are some technological operations that lead to evaporation, oxidation, contamination of fuel with dust, and sedimentation. Thus, in general, the fuel when filling the rolling stock deviates from the technical requirements of the DSTU [9].

Improving any performance of motor fuels by changing their chemical composition requires huge costs. At the same time, certain properties of motor fuels may be changed by additives, which allows a positive effect equivalent to a change in production technology. Oil refineries of all developed countries introduce various additives into motor fuels; the world market offers more than 1000 additives, the purpose and classification of which are detailed in papers [3-5]. Consumption of additives to motor fuels in the United States reaches 100,000 tons per year. Additive manufacturers accentuate the benefits of their products but keep, in most cases, their composition a secret.

The patent literature review shows that most of the proposed additives cannot be used as they increase the toxicity of exhaust gases, impair the properties of fuels, significantly increase the cost of fuel. Some additives used are currently banned for environmental (containing lead, barium, manganese) and operational reasons [6-8].

Objective and tasks. The objective of the research is to analyze and generalize the experience and develop a proposal for the application of effective measures and means to improve the quality of diesel fuel for diesel locomotives. The task of the research is to:

- analyze the experience of applying chemmotological measures to improve the quality of diesel fuel for locomotives;
- determine technical requirements for chemmotological measures to improve the quality of diesel fuel for locomotives;

- develop their efficiency assessment technique in the locomotive depot settings.

Main part. Currently, the production and use of additives in Ukraine are only gaining their industrial potential, while products in demand are still mainly foreign additives. The cost of imported anti-wear additives is usually higher, as raw materials are purchased at foreign factories and delivered back as a marketable product.

At the request of Ukrzaliznytsia, SE Malyshev Plant has conducted bench tests of samples of six diesel fuel additives of different manufacturers.

None of the presented diesel fuel additives proved their effectiveness in the tests conducted following the requirements of JSC Ukrzaliznytsia.

That is:

- the difference between the results of measurements of fuel consumption with and without additives is within the experimental error;

- the effect on the concentrations of pollutants in the exhaust gases of a diesel engine in the test modes is such that the difference between the concentrations of pollutants in the exhaust gases during the operation of a 7D80A diesel engine on fuel with and without additives is a few percent;

- the effect of additives on smoking of the exhaust gases was within the smoke meter error $( \pm 1 \%)$;

- the tests found no significant effect of additives on such basic indicators of the operating process as maximum combustion pressure (average) on $\mathrm{P}_{\mathrm{z}}^{\mathrm{av}}$ cylinders, the temperature of exhaust gases near cylinders $\mathrm{t}_{\mathrm{c}}{ }^{\mathrm{av}}$, frequency of rotation of a rotor of the turbocharger $\mathrm{n}_{\mathrm{tc}}$, excess air pressure in the receiver $\mathrm{P}_{\mathrm{s}}{ }^{\mathrm{exc}}$, exhaust gas pressure before the turbine $\mathrm{P}_{\mathrm{S}}{ }^{\text {exc }}$;

- the tests found no effect of additives on fuel equipment, diesel oil, and fuel filters. 
More thorough conclusions about the effect of additives on the above parameters require operational tests.

The use of additives in the operation of locomotives sets the question of their introduction technique to diesel fuel. In addition to accurate dosing, additives must be evenly distributed in the fuel. As a rule, manufacturers neglect it, and the high-quality introduction and distribution of additives in diesel fuel may require creating the necessary technological equipment.

Thus, it is necessary to conduct research aimed at formulating technical requirements for the additive to diesel fuel for diesel locomotives, which has an integrated effect.

Another way of changing the quality of diesel fuel is the physical impact - the use of additional hydrodynamic, magnetic, electrodynamic, or ultrasonic treatment. For this, the specialists of Ukrainian State Railway Academy have developed and tested a method to improve the anti-wear and anti-corrosion properties of diesel fuel to increase the wear resistance of fuel equipment of diesel engines through hydrodynamic dispersion [10].

The specialists of Ukrainian State Railway Academy also took part in bench tests of the cavitation reagent-free diesel fuel treatment device. It is used to change the properties of liquid products and mixtures.
This technology is a series of measures based on the principles of hydrodynamic cavitation, leading to the rupture of polymer bonds, i.e. obtaining low molecular weight compounds, and as a consequence, changes (facilitation) of the fractional composition of the treated diesel fuel [11].

Both measures affect the physicochemical properties of diesel fuel but do not provide significant savings in diesel fuel, however, the physical treatment of fuel is still feasible.

Thus, it may be necessary to consider integrated devices for changing the quality of diesel fuel. That is, devices that have an additional physical effect on and dose additives to diesel fuel.

An example of such a device is a KT14D fuel catalyst, which is also an additional diesel fuel fine filter that pre-modifies diesel fuel using a tableted granular additive catalyst.

The device is installed in the fuel supply system of the diesel locomotive, and by actively influencing the fuel, prevents the formation of harmful substances, increases the technical performance of the internal combustion engine.

The first chamber is where sedimentation of heavy fractions, which have got to fuel, and selective purification of diesel fuel from sulfur compounds and pitches occur.

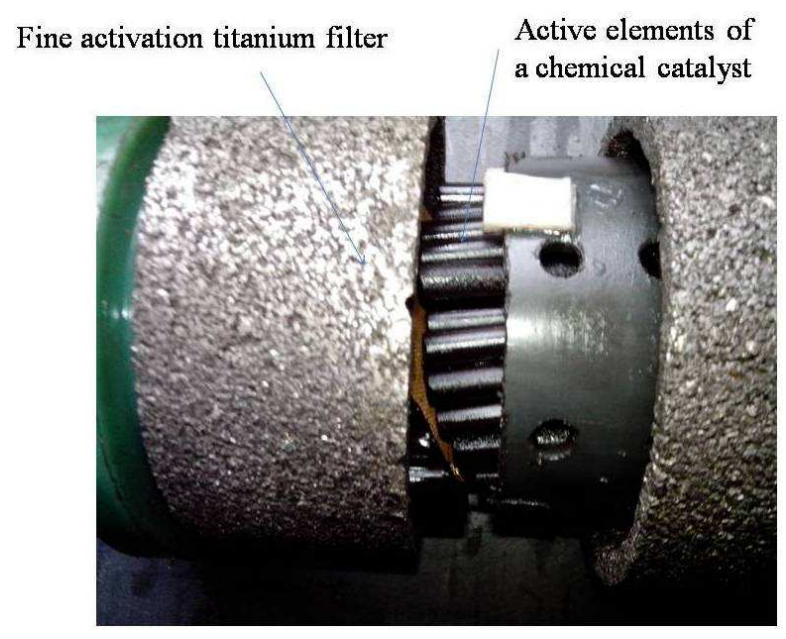

Fig. Fine activation titanium filter with active elements 
The device is installed in the fuel supply system of the diesel locomotive, and by actively influencing the fuel, prevents the formation of harmful substances, increases the technical performance of the internal combustion engine.

The first chamber is where sedimentation of heavy fractions, which have got to fuel, and selective purification of diesel fuel from sulfur compounds and pitches occur.

In the second chamber, the fuel is catalytically treated by contacting its hydrocarbon molecules with a highly porous active surface of the granular catalyst, which includes compounds of metals and catalytically active organic compounds. After that, the fuel is processed at the molecular level by tableted additives, metal salts, which are formed under the influence of high temperatures and pressure during combustion in the cylinder chamber in the form of molecules.

In the third chamber, modified fuel is subjected to additional activation and stabilization due to the use of titanium glasses activators. The effect of catalytic fuel treatment lasts for 30-40 seconds. Integrated fuel treatment enhances complete combustion, thereby reducing fuel consumption and release of harmful substances into the atmosphere with exhaust gases.

The integrated diesel fuel treatment plant has passed many bench and operational tests in the locomotive depot and has shown its influence on fuel consumption and environmental performance of the locomotive. To determine the efficiency, we need to conduct operational tests on different series of diesel rolling stock.

To assess the effectiveness of chemmotological measures in operational tests of locomotives, it is necessary to determine the nature of the change in time of the main indicators [12]. Therefore, it is important to determine:
- change in the volume of work performed in operation;

- fuel and engine oil consumption for the work performed;

- expenditure of funds for repairs in operation.

As a criterion for the cost of repairs let us take specific costs in UAH per $1000 \mathrm{~km}$, i.e.:

$$
C_{\text {num }}=\frac{B}{L^{\prime}} \cdot 10^{3}
$$

where $B$ is the unit cost of repair;

$L^{\prime}$ is the time between overhaul.

Thus, it is possible to obtain proportional coefficients for the economic evaluation of the efficiency of locomotives, representing the useful work costs in UAH; knowing the cost of one ton-kilometer, one $\mathrm{kg}$ of fuel and oil, we get:

$$
E_{\mathrm{x}}(t)=A\left[c_{1}-\left(g_{T} c_{2}+g_{M} c_{3}\right)\right]-c_{n u m} \mathrm{~L}
$$

where $E_{\mathrm{x}}(t)$ is the efficiency of the diesel generator;

$A$ is the volume of transportation work performed;

$g_{T} g_{M}$ is fuel and oil consumption per $\mathrm{km}$;

$c_{1}$ is the cost of 1 tonne-km gross;

$c_{2} c_{3}$ is the cost of one $\mathrm{kg}$ of fuel and oil, respectively;

$c_{n u m}$ is the specific cost of repairs attributed to one $\mathrm{km}$;

$\mathrm{L}$ is the total mileage during time $t$.

To assess the effectiveness of operational tests of locomotives in locomotive depots, an optimization model with the following objective function is proposed, which considers the dynamic characteristics of the main components of efficiency in the form of: 


$$
\begin{gathered}
E=\frac{\int_{l_{1}}^{l}\left[c_{1} \varphi_{\Pi}(l)+c_{2} \varphi_{M}(l)+c_{3} \varphi_{H}(l)\right] d l}{\int_{l_{1}}^{l}\left[c_{1} \varphi_{\Pi}^{\prime}(l)+c_{2} \varphi_{M}^{\prime}(l)+c_{3} \varphi_{H}^{\prime}(l)\right] d l} \Rightarrow \max , \\
l_{1} \leq l \leq l_{p},
\end{gathered}
$$

where $l_{1}$ is the initial mileage of the implementation of the technical solution;

$l_{p}$ is mileage before overhaul, where the effectiveness of the implementation of the experimental technical solution is evaluated;

$\varphi_{\Pi}(l)$ is the relationship of fuel consumption to mileage; mileage;

$\varphi_{M}(l)$ is the relationship of engine oil to to mileage.

$\varphi_{H}(l)$ is the relationship of repair costs

The given target function is based on the assumption that oil fuel consumption and repair costs are independent of each other.

This optimization model is the basis of automated technology for operational tests in locomotive depots.

To quantify the effectiveness of operational tests, we need to obtain the average monthly dynamics of diesel fuel, oil, and repair costs, as well as to calculate the average monthly dynamics of the integrated efficiency of the tested resource-saving measures.

Conclusions. Thus, the application of chemmotological measures to improve the quality of diesel fuel can optimize changes in the technical condition of diesel engines, reduce diesel fuel consumption, improve the environmental performance of locomotive engines, which will reduce the cost of locomotive depots for the environment. Preliminary tests of measures showed positive changes in technical, economic, and environmental parameters (reduction of fuel consumption in operation, reduction of specific consumption in rheostatic tests) of the locomotive and improvement of the technical condition of the locomotive engine. It is expedient to conduct the comprehensive operational tests of the proposed measures, with the assessment of the effectiveness of resource-saving measures according to the proposed integrated criterion for assessing the efficiency of locomotives during operational tests in the depot settings.

\section{References}

1. Aulin D., Zinkivskyi A., Anatskyi O., Kovalenko D. (2018) Measures for Resource Saving for Diesel Locomotives. International Journal of Engineering \& Technology, 7, 152-156.

2. Tartakovskyi E. D., Aulin D. O., Artemenko O. V. (2013) Raboty kafedry ERPS UkrHAZT po vnedrenyiu resursosberehaiushchykh tekhnolohyi v lokomotyvnom khoziaistve. Visnyk Skhidnoukrainskoho natsionalnoho universytetu im. Volodymyra Dalia, 4, 243-246.

3. Danylov A.M. (2005) Prymenenye prysadok k toplyvu. Moskva, Myr 288 s.

4. Mytusova T.N. (2009) Sovremennoe sostoianye proyzvodstva dyzelnykh toplyv. Nauchnotekhnycheskyi zhurnal. Myr nefteproduktov. Vestnyk neftianykh kompanyi, 9, 6-16.

5. Mytusova T. N., Polyna E. V., Kalynyna M. V. (2002) Sovremennye dyzelnye toplyva y prysadky k nym. Moskva, Tekhnyka, $64 \mathrm{~s}$. 
6. Tina Kegl, Anita Kovač Kralj, Breda Kegl, Marko Kegl. (2020) Nanomaterials as fuel additives in diesel engines: A review of current state, opportunities, and challenges. Combustion Science, 83, doi.org/10.1016/j.pecs.2020.100897

7. Xinda Zhu, Öivind Andersson. (2020) Performance of new and aged injectors with and without fuel additives in a light duty diesel engine. Transportation Engineering, 1, doi.org/10.1016/j.treng.2020.100007

8. Gabriel Popa, Marius Alin Gheți. (2020) Locomotive Diesel Engine Operation with Optimal Specific Fuel Consumption. Procedia Manufacturing, 46, 440-444. URL: doi.org/10.1016/ j.promfg.2020.03.064

9. Levytyn R. E. (2007) Yzmenenye kachestva nefteproduktov v protsesse dostavky ykh potrebyteliu. Neftehazovoe delo. URL: http://www.ogbus.ru,

10. Ventsel Ye. S., Zhalkin S. H., Kravets A. M., Sadiiev S. A. (2002) Pidvyshchennia protyznoshuvalnykh vlastyvostei dyzelnoho palyva hidrodynamichnym dysperhiruvanniam. $Z b$. nauk. prats. UkrDAZT, Kharkiv, 50, 88-94.

11. Obrabotka dyzelnoho toplyva kavytatsyonnym vozdeistvyem. URL: http://www.kavitus.com/ru/?q=tech/obrabotka-dyzelnoho-toplyva-kavytatsyonnym-vozdeistvyem.

12. Tartakovskyi E. D., Aulyn D. O., Androsov D. S. (2011) Vyznachennia efektyvnosti khimmotolohichnykh zakhodiv pidvyshchennia efektyvnosti teplovoziv v ekspluatatsii. Sbornyk nauchnykh trudov "Vestnyk NTU "KhPY": Novi rishennia v suchasnykh tekhnolohiiakh, 34, 67-71.

Kostyrya Ivan, chief manager of the locomotive department "KTZ-FREIGHT TRANSPORTATION” JSC.

Tel.: + 8 (7172) 60-30-30, E-mail: dimmo@ex.ua.

Liubenko Petr Yvanovych - CEO TOV NVF EKO-AVTO-TITAN. Tel.: +380972233851. E-mail: eco-at@ukr.net.

Artemenko Oleksandr, PhD (Tech.), head of production and technical department Lozova Locomotive Depot of the

"Southern Railway" JSC "Ukrzaliznytsia". Tel.: +38 (050) 9544355. E-mail: my.pochta77@ukr.net.

Aulin Dmitriy, PhD (Tech.), Senior lecturer, of Department "Exploitation and Repair of Rolling Stock", Ukrainian State University of Railway Transport, Kharkiv, Ukraine. ORCID iD: 0000-0002-7990-4808. Tel.: +38 (057) 730-19-98.

E-mail: aulin@kart.edu.

Костиря Іван Іванович, головний менеджер департаменту локомотивного господарства ТОО "КТЖ-Грузовые перевозки"(Казахстан). Тел:+ 8 (7172) 60-30-30. E-mail: dimmo@ex.ua.

Любенко Петро Іванович, генеральний директор ТОВ НВФ ЭКО-АВТО-ТИТАН Тел:+380972233851.

E-mail: eco-at@ukr.net.

Артеменко Олександр Вікторович, кандидат технічних наук, начальник виробничо-технічного відділу

"Локомотивного депо Лозова" РФ "Південна залізниця" АТ "Укрзалізниця" Тел: +38 (050) 9544355.

E-mail: my.pochta77@ukr.net.

Аулін Дмитро Олександрович, кандидат технічних наук, старший викладач кафедри експлуатації та ремонту рухомого складу Українського державного університету залізничного транспорту. ORCID iD: 0000-0002-79904808. Тел:+38 (057) 730-19-98. E-mail: aulin@kart.edu.

Статтю прийнято 30.11.2020 p. 